\title{
THE MORPHOLOGY OF POLLEN GRAINS OF THE SOME SPECIES OF ROSACEAE JUSS. FAMILY
}

\author{
Motyleva Svetlana', Brindza Jan², Kulikov Ivan ${ }^{1}$ \\ ${ }^{1}$ Federal state budgetary scientific institution "All-Russian Horticultural Institute for Breeding, \\ Agrotechnology and Nursery" (ARHIBAN), Moscow, Russia \\ ${ }^{2}$ Faculty of Agrobiology and Food Resourses, Slovak University of Agriculture in Nitra, Slovak Republic
}

Received 25. 6. 2017

Revised 28. 6. 2017

Published 29.11.2017

\begin{abstract}
Features of pollen grains, sculpture 2 species Rosaceae Juss. (Malus domestica Borkh and Pyrus communis L.) has been studied in detail using scanning electron microscopy method. The pollen material is picked up in Slovak Republic, was used in the study. Shape of the pollen grains is oblong-ellipsoidal. In terms of poles, the grain is round. The pollen grains Malus domestica and Pyrus communis has - 3 colossus, the hole is long. A complex type of exine is characteristic of the studied species of Rosaceae. The average size of the poles axis of pollen grains is Malus domestica trees is in the range of $27.91-36.62 \mu \mathrm{m}$, the equatorial diameter is in the range of 13.28-17.17 $\mu \mathrm{m}$. The average size of the pole axis of pollen poles of Pyrus communis trees is $38.83-56.83 \mu \mathrm{m}$, the equatorial diameter is $20.26-29.92 \mu \mathrm{m}$. The ratio of the pole axis to the equatorial $(\mathrm{P} / \mathrm{E})$ is the degree of elongation of the pollen grains (roundness). The pollen of Malus domestica breeds is more elongate compared with the pollen of Pyrus communis. Pollen of Malus domestica rocks are more elongated compared with the pollen of Pyrus communis (P/E is $14 \%$ more). The traits analysed could be useful for plant breeders or for gene bank curators at the first steps of identification of cultivars, since the analysis is simpler and less expensive than other methods.
\end{abstract}

Keywords: Malus domestica Borkh.; Pyrus communis L.; pollen morphology; scanning electron microscopy

\section{Introduction}

Many of the species of Malus domestica Borkh. and Pyrus communis L. are complex hybrids, and among the forms of wild plants, there are many interspecific hybrids, complicating classification. That's why the ability to identify morphological features of pollen grains of Apple and pear, using not only external features, but also microstructures with the use of modern equipment is of great interest.

Analysis of morphology and ultrastructure of pollen grain by electron microscopy (transmission and scanning) may be useful for distinguishing species and cultivars (Shivana, 2003). Pollen ultrastructure has been used to distinguish cultivars of apple (Currie et al., 1997; Martens and Fretz, 1980; Marcucci et al., 1984), pear (Westwood and Challice, 1978). The complex of morphological characteristics allows to determine the differences (or similarities) between close species or breeds, morphological heterogeneity, especially the variability of their sizes due to hybridization, polymorphism (Куприянова и Алешина, 1978; Palinological Database; Tzarenko, 2012).

*Corresponding author: Svetlana Motyleva, Federal state budgetary scientific institution "All-Russian Horticultural Institute for Breeding, Agrotechnology and Nursery" (ARHIBAN), Moscow, Russia, $\triangle$ motyleva_svetlana@mail.ru 
Thus, the study of the morphology of pollen grains - the size, shape, structure of exine, the number of holes and locations, in our opinion, is quite relevant. Comparative electron microscopic studies of the pollen of Malus domestica and Pyrus communis grown in Slovakia was not carried out earlier; this determined the aim of our study.

\section{Materials and methodology}

For the evaluation we removed the pollen from the apple trees - cultivar Júlia and from the pear trees - cultivar Conference grown in the demonstration garden of the Slovak University of Agriculture in Nitra.

Pollen was taken mechanically from the flowers in full flowering. Microstructures are taken on the scanning electronic microscope Carl Zeiss LS 15 in the Institute of Biodiversity and Biological Safety of Slovak Agricultural University in Nitra by PhD of Agriculture S.M. Motyleva. To collect pollen samples, branches with flower buds in the "balloon" stage were collected and transported to the laboratory, where anthers were isolated from the flower buds, placed in petri dishes $(\varnothing 7 \mathrm{~cm})$ and dried at room temperature $\left(24 \mathrm{~h}\right.$ ) until anther dehiscence. Pollen was collected in small vials and stored at $3-5{ }^{\circ} \mathrm{C}$ in a desiccator containing silica-gel. Preliminary dried pollen was put on the special carbonic scotch placed on the object table of the scanning electronic microscope with a thin metal spreading rod. The comparative morphological studying of the pollen grains was performed according to the working rules on the Carl Zeiss LS 15 : 500 times - during the measurements; 1,000-10,000 times - while taking the pictures of the exine sculpture features. The measurements of the pollen grains linear dimensions were performed via 100-200 times repeatability in not less than 10 microscope fields with the average value calculation. All the mentioned in the text dimensions are given in um. The data were analyzed using statistical software.

\section{Results and discussion}

The pollen grains morphometric values are given in Table 1.

Table 1 The morphological characteristic of family Rosaceae Juss. representatives pollen grains

\begin{tabular}{|c|c|c|c|c|c|}
\hline Measurements & $n$ & Min & Max & $x$ & $\mathbf{V}, \%$ \\
\hline \multicolumn{6}{|c|}{ Pyrus communis L. } \\
\hline$P, \mu \mathrm{m}$, & 250 & 38.83 & 56.83 & 47.83 & 8.86 \\
\hline$E, \mu \mathrm{m}$ & 250 & 20.26 & 29.92 & 25.09 & 8.04 \\
\hline$P / E$ & 250 & 1.91 & 1.89 & 1.9 & - \\
\hline \multicolumn{6}{|c|}{ Malus domestica Borkh. } \\
\hline$P, \mu \mathrm{m}$ & 200 & 27.91 & 36.62 & 36.22 & 6.83 \\
\hline$E, \mu \mathrm{m}$ & 200 & 13.28 & 17.01 & 15.15 & 5.62 \\
\hline$P / E$ & 200 & 2.1 & 2.15 & 2.12 & \\
\hline
\end{tabular}

$P$ - length of polar axis; $E$ - the length of the Equatorial axis; $(P / E)$ - form index; $n$ - number of measurements; min - minimum measured value; max - maximum measured value; $x$ - arithmetic average; $V, \%$ - variation coefficient 
The average size of the pole axis for the Malus domestica studied breeds pollen grains is within 27.1-36.22 $\mu \mathrm{m}$; the equatorial diameter is within 13.28-17.01 $\mu \mathrm{m}$. The average size of the pole axis for the Pyrus communis studied breeds pollen grains is within $36.49-39.78 \mu \mathrm{m}$; the equatorial diameter is within 14.35-19.31 $\mu \mathrm{m}$. The equatorial length of the pollen grains was generally much greater than the polar length. The ratio of the pole axis to the equatorial one $(P / E)$ marks the degree of the pollen grains elongation (roundness). The pollen of Malus domestica breeds is more elongate compared with the pollen of Pyrus communis Pollen of Malus domestica rocks are more elongated compared with the pollen of Pyrus communis (P/E is $14 \%$ more).

Pascoe (2007) reported that Malus domestica is a non-operculate, trizonocolporate pollen grain that is narrowly elliptic to rhombic-obtuse. Sculpturing can be finely regulating to somewhat striate. Colpus is deep but terminating at the poles but widening slightly at this point also. Our results support this finding.

The pollen grains form is oblong-ellipsoid, cultivars examined were elliptical and trizonocolporate with subdivision of the surface area into three equal parts (Figure 1A, B). The exine pattern is tenderundulate, fine-mesh, the picture has the breed features. The poles of the grain are round. A significant presence of pits on exine was seen. Axine is complicated. The obtained pictures clearly show that the pollen grains of the represented species of the family Rosaceae are 3 colporate.
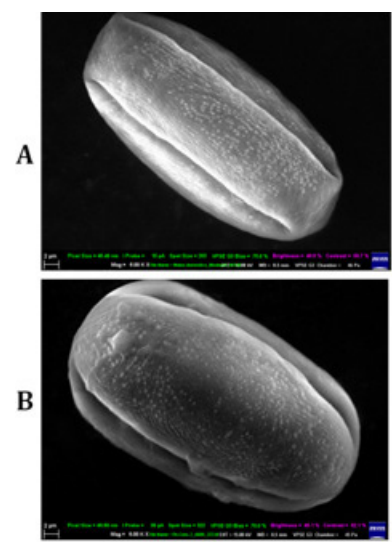

1
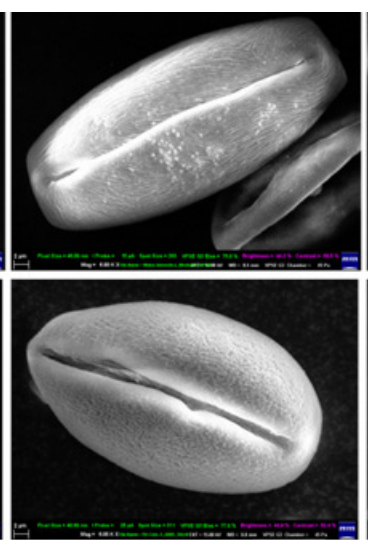

2
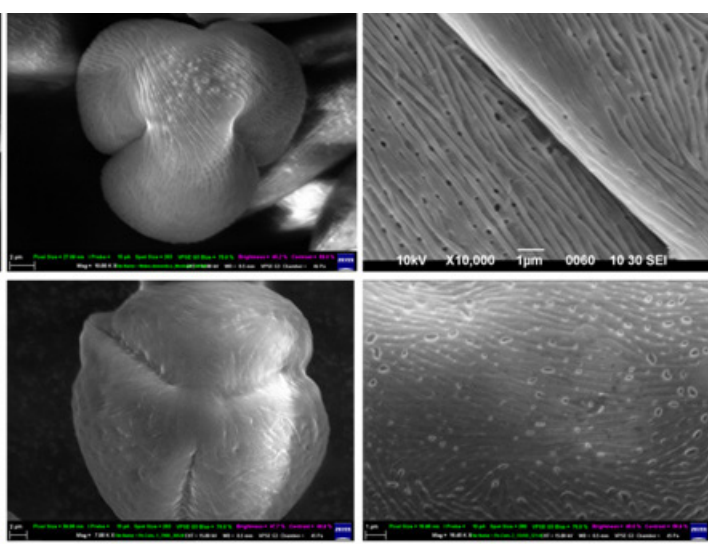

3

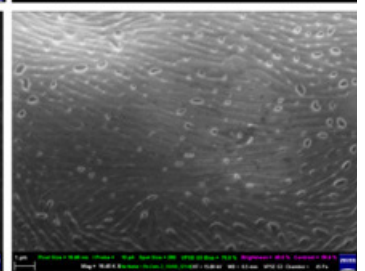

4

Figure 1 Scanning electron micrographs (SEM) images of pollen grains

A - Malus domestica Borkh., B - Pyrus communis L.; 1,2 - equatorial view; 3 - polar view; 4 - surface view of grain.

The number of the misshapen pollen grains is up to $15-25 \%$. This fact, in some ways, can be connected with the greenness of some pollen.

\section{Conclusions}

The studying of the Malus domestica and Pyrus communis pollen via scanning electronic microscopy allowed to separate the most important parameters which can be used to identify the representatives of the family Rosaceae. They are the form (the pollen grains elongation, the length and the width ratio and the surface picture (microsculpture). The pollen is tricolpate. The traits analyses could be useful for plant breeders or for gene bank curators at the first steps of identification of cultivars, since the analysis is simpler and less expensive than other methods. 


\section{Acknowledgments}

The publication was prepared with the active participation of researchers in international network AgroBioNet, as a part of international program "Agricultural biodiversity to improve nutrition, health and quality of life" (TRIVE ITMS26110230085) within the project AgroBioTech ITMS 26220220180. Co-author Svetlana Motyleva (№ 51700373) is grateful to the Agency Visegrad Fund for providing a scholarship for the research internship, during which she received the results and knowledge presented in this paper.

\section{References}

Currie, A.J., Noiton, D.A., Lawes, G.S., Bailey, D. 1997. Preliminary results of differentiating apple sports by pollen ultrastructure. Euphytica, vol. 98, no. 3, p. 155-161. http://dx.doi.org/10.1023/A:1003174529263

Marcucci, M.C., Sansavini, S., Ciampolini, F., Cresti, M. 1984. Distinguishing apple clones and cultivars bysurface morphology and pollen physiology. J. Am. Soc. Hortic. Sci., vol. 109, p. 10-19.

Martens, J., Fretz, T.A. 1980. Identification of eight crabapples by pollen surface sculpture. J. Am. Soc. Hortic. Sci., vol. 105, p. 257-263.

PalDat - Palinological Database. http://www.paldat.org/

Pascoe, M.S. 2007. SEM: pollen images of selected british flora: towards development of a national database. $258 \mathrm{p}$.

Shivana, K.R. 2003. Pollen Biology and Biotechnology (Enfield, NH, USA: Science Publishers, Inc.).

Tzarenko, L.V. 2012. The pollen analysis in the plants selection. In: Scientific magazine KubGAU, vol. 77, no. 3, p. 1-11. http://ej.kubagro.ru/2012/03/pdf/09.pdf

Westwood, M.N. Challice, J.S. 1978. Morphology and surface topography of pollen and anthers of Pyrus species. J. Amer. Soc. Hort. Sci., vol. 103, p. 28-37.

Куприянова, Л.А., Алешина, Л.А. 1978. Пыльца двудольных растений фрлоры Европейской части СССР. Laminaceae - Zygophyllaceae. Л.: Наука, с.111. 